Deans and Truants 



\section{Deans and Truants}

Race and Realism in

African American Literature

GENE ANDREW JARRETT

$\overline{\text { PENN }}$

University of Pennsylvania Press

Philadelphia 
Copyright (C) 2007 University of Pennsylvania Press

All rights reserved

Printed in the United States of America on acid-free paper

$\begin{array}{llllllllll}10 & 9 & 8 & 7 & 6 & 5 & 4 & 3 & 2 & 1\end{array}$

Published by

University of Pennsylvania Press

Philadelphia, Pennsylvania 19104-4112

Library of Congress Cataloging-in-Publication Data

Jarrett, Gene Andrew, 1975-

Deans and truants : race and realism in African American literature / Gene Andrew Jarrett. p. $\mathrm{cm}$.

Includes bibliographical references and index.

ISBN-13: 978-0-8122-3973-7 (acid-free paper)

ISBN-10: 0-8122-3973-3 (acid-frec paper)

1. American literature-African American authors - History and criticism. 2. African Americans-Intellectual life. 3. African Americans in literature. 4. African American aesthetics. 5. Race in literature. 6. Realism in litcraturc. I. Title.

PS153.N5J395 2006

$81.9^{\prime} 352996073-\mathrm{dc} 22$ 
For the joys of my life,

Renée and Nyla,

and in memory of an excellent scholar,

Claudia Tate (1946-2002) 
